Revista de Metalurgia 52(3)

July-September 2016, e073

ISSN-L: 0034-8570

doi: http://dx.doi.org/10.3989/revmetalm.073

\title{
Effect of Ekabor 2 powder on the mechanical properties of pure iron powder metal compacts
}

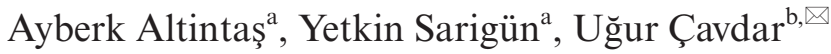 \\ ${ }^{a}$ Celal Bayar University, Mechanical Engineering Department, Muradiye Campus, 45400 Manisa, Turkey \\ ${ }^{b}$ Celal Bayar University, Vocational School, Department of Machinery, Turgutlu Campus, 45400 Manisa, Turkey \\ Corresponding author: ugur.cavdar@cbu.edu.tr
}

Submitted: 13 November 2015; Accepted: 8 May 2016; Available On-line: 14 October 2016

\begin{abstract}
Ekabor 2 powder of different weights, used by V type powder mixture was mixed with pure iron powder. Specimens were created by dry pressing into die followed by cold isostatic press at a pressure of $100 \mathrm{bar}$ for purpose of resizing. The conventional sintering process at $900{ }^{\circ} \mathrm{C}$ and $950{ }^{\circ} \mathrm{C}$ was carried out for $4 \mathrm{~h}$ using conventional furnaces. Specimens were gradually cooled by air. The sintered pellets were examined in terms of density, wear abrasion, surface roughness and hardness at $900{ }^{\circ} \mathrm{C}$ and $950{ }^{\circ} \mathrm{C}$. Microstructure of pellets was observed with optic microscope. The results show that the hardness gradually increased with additions of $0 \mathrm{wt}$. \% to $10 \mathrm{wt}$. \% of Ekabor 2 however, after $10 \mathrm{wt}$ \%, this hardness tended to decrease.
\end{abstract}

KEYWORDS: Conventional sintering; Ekabor 2; Mechanical properties; Powder metal compact; Pure iron

Citation / Cómo citar este artículo: Altintaş, A., Sarigün, Y., Çavdar, U. (2016) "Effect of Ekabor 2 powder on the mechanical properties of pure iron powder metal compacts". Rev. Metal. 52 (3):e073. doi: http://dx.doi.org/10.3989/ revmetalm.073

RESUMEN: Efecto del polvo "Ekabor 2" en las propiedades mecánicas del hierro puro como material compacto pulvimetalúrgico. Se mezclaron diferentes cantidades de polvo denominado "Ekabor 2", el cual se utiliza en mezclas de polvo tipo $\mathrm{V}$, con hierro puro en polvo. La muestras se obtuvieron por prensado en seco seguido de prensa isostática en frío a una presión de 100 bar, con el objeto de redimensionar la muestra. Se llevó a cabo el proceso de sinterización convencional a $900{ }^{\circ} \mathrm{C}$ y $950{ }^{\circ} \mathrm{C}$ durante $4 \mathrm{~h}$ utilizando hornos convencionales. Las muestras se enfriaron gradualmente en aire. Las pastillas sinterizadas (pellets) se examinaron en términos de densidad, resistencia a la abrasión, rugosidad y dureza a $900{ }^{\circ} \mathrm{C}$ y $950{ }^{\circ} \mathrm{C}$. Se observó la microestructura de las pastillas por microscopía óptica. Los resultados mostraron un aumento gradual de la dureza con la adición de $0 \%$ en peso a $10 \%$ en peso de polvo Ekabor 2. Sin embargo, para mayores cantidades del 10\% en peso se observó una tendencia a disminuir en la dureza.

PALABRAS CLAVE: Ekabor 2; Hierro puro; Polvo de metal compacto; Propiedades mecánicas; Sinterización

Copyright: (C) 2016 CSIC. This is an open-access article distributed under the terms of the Creative Commons Attribution License (CC-by) Spain 3.0. 


\section{INTRODUCTION}

Powder Metallurgy (PM) is a term covering a wide range of ways in which materials or components are made from metal powders. This process owe its popularies to its low energy consumption and high benefit with low production costs. Different grain sizes are generated for purpose of different applications, compressed for forming and heated up for resistance and finally their properties are checked. (Schatt and Wieters, 1997; German, 2005).

Sintering is the process of compacting and forming a solid mass of material by heat and/or pressure without melting it to the point of liquefaction. During sintering process, binder is burned, particles are interconnected and changing of size and grain growth are seen in microstructure (Çavdar and Atik, 2011).

Induction sintering is applied with variable currentcarrying conductor coil. A source of high frequency electricity is used to drive a large alternating current through a coil. This causes tremendous currents to flow through the workpiece (German, 1996). Microwave sintering is mostly applied to ceramics. This method is carried out with $9 \mathrm{~kW}$ power source (Clark et al., 1993). Although Spark Plasma Sintering (SPS) is smilar to microwave sintering, SPS carried out fast sintering with its own thermal environment. Commonly, this method is performed on $\mathrm{Al}_{2} \mathrm{O}_{3}, \mathrm{SiC}$ and $\mathrm{ZrO}_{2}$ (Upadhya, 1987; Kasai et al., 1989).

Cavdar and Atik used pure iron, 3 wt.\% copper or $3 \mathrm{wt}$ \% bronze mixed iron powders. Iron based $\mathrm{PM}$ compacts were sintered at $1120^{\circ} \mathrm{C}$ by mediumfrequency induction heat sintering (MFIHS) in 8.33 min $(500 \mathrm{~s})$. Results in MFIHS are compared with conventional sintering at $1120{ }^{\circ} \mathrm{C}$ in $30 \mathrm{~min}$. Mechanical properties of these samples were investigated (Çavdar and Atik, 2014a).

Calık different used powder with different grain sizes (Ekabor 1, Ekabor 2, Ekabor 3, Ekabor HM) for boronizing. In this work, EN H320 LA steel sheets were used and boride layers were compared with each other. The boronizing was done at $700,800,900{ }^{\circ} \mathrm{C}$ for $3 \mathrm{~h}$. The result obtained shows that, tensile properties were affected by the boronizing powders as temperature increased (Çalik, 2013).

In the study regarding boronizing, Taştan et al. (2009) who expect surface of hardness work on different compositon of materials. AISI 1020, AISI 1040, AISI 4140, H13 steels were used as materials for boronizing. The boronizing was carried out in $820^{\circ} \mathrm{C}, 860{ }^{\circ} \mathrm{C}, 900^{\circ} \mathrm{C}$ and $940{ }^{\circ} \mathrm{C}$ in 2 , $4,6,8 \mathrm{~h}$. Ekabor 2 was used for boronizing source. The thickness of the borize layer increased with increasing particle size of boronizing powders and with increasing boronizing temperature (Taştan et al., 2009).

Çelik et al. (2008) investigated the impact of thermal processing conditions on abrasive wear; and surface properties of borided AISI 1030 steel were analysed. Boroding was applied at 900, 950, 1000, $1050{ }^{\circ} \mathrm{C}$, in 2, 4, $6 \mathrm{~h}$ by using Ekabor 2 powders. Result of the experimental studies show that borided layer thickness increases depending on boriding heat treatment temperature and time. It was discovered that the wear resistance in AISI 1030 steel increased much more than none treated samples according as borided layer properties (Çelik et al., 2008).

Barut et al. (2014) borided AISI 5140 steel and AISI 420 stainless steel at 850,900 and $950{ }^{\circ} \mathrm{C}$ for dwell times of 2, 4 and $6 \mathrm{~h}$. In XRD analysis, FeB, $\mathrm{Fe}_{2} \mathrm{~B}, \mathrm{CrB}$ and $\mathrm{MnB}$ phases were seen on the boride layer. While the real hardness amounts of AISI 5140 and AISI 420 steels were approximately $265 \mathrm{HV}$ and $340 \mathrm{HV}$. As result of boriding, they increased up to $1843 \mathrm{HV}$ and $1972 \mathrm{HV}$. Activation energies (Q) of borided AISI 5140 steel and AISI 420 stainless steel used in the current study were determined as 194.951 and $206.161 \mathrm{kJ.mol}^{-1}$, respectively (Barut et al., 2014).

Turku, et al. (2014) made boronizing to low carbon microalloyed steels at $850{ }^{\circ} \mathrm{C}$ under various exposure times using Ekabor 2 commercial powders. It was concluded that boride layer thickness and hardness amounts increase with increasing boriding time due to hard boride phases and diffusion as a result of boronizing process (Turku et al., 2014).

Günen et al. (2013) used AISI 304 austenitic stainless steel for surface boriding. They made boronizing with elemental nanoboron powder of 10 to $50 \mathrm{~nm}$ in size hexagonal boron nitride powder of 50 to $100 \mathrm{~nm}$ in size and Ekabor 3 powder of $1400 \mu \mathrm{m}$ in size at $900{ }^{\circ} \mathrm{C}$ in dwell time $3 \mathrm{~h}$. Consequently, it has been identified that thickness, hardness and fracture toughness amounts increased with the decrease of boriding powder grain structure (Günen et al., 2013).

Other experiment about boronizing process was done by Usta and Ekmekciler. FeAl was used as material. The temperature of boriding was $875^{\circ} \mathrm{C}$, $940{ }^{\circ} \mathrm{C}, 1040^{\circ} \mathrm{C}$ for $2,4,8 \mathrm{~h}$. The thickness of boride layer was measured between $8 \mu \mathrm{m}-60 \mu \mathrm{m}$ and hardness was found from $1290 \mathrm{HV}$ to $1500 \mathrm{HV}$ (Usta and Ekmekciler, 2010).

Sometimes, the boriding process can't make better mechanical properties of metarial. In this study, pure cobalt (Co) was boronized at $900{ }^{\circ} \mathrm{C}$ and $1000^{\circ} \mathrm{C}$ for $1,3,6 \mathrm{~h}$ by Çalik et al. (2014). In conclusion, despite the increase of temperature and time, a significant change wasn't determined at the parameters (Calik et al., 2014).

Boronizing process, salt bath and powder pack, was used martensitic stainless steel AISI 420 by Juijerm (2014). The temperature of process was $850^{\circ} \mathrm{C}-950^{\circ} \mathrm{C}$ for $9 \mathrm{~h}$. The empirical relationships of boride thickness was related between time and temperature in the study (Juijerm, 2014).

The other boronizing process was done by Jurci et al. (2012). Process was carried out at $1030{ }^{\circ} \mathrm{C}$ for $30 \mathrm{~min}, 45 \mathrm{~min}, 75 \mathrm{~min}, 150 \mathrm{~min}$. H11 hot work tool 
steel was used as material. Better result was found at the intermediate region and they developed new carbides which were identified as $\mathrm{M}_{23} \mathrm{C}_{6}$. The hardness of boride layer is depended on time and temperature like the other studies (Jurci et al., 2012).

The last study which examined was done by Ptacinova et al. (2015). In this study, plain, low carbon steel S235JRG1 was boronized at $1000{ }^{\circ} \mathrm{C}$ for $45 \mathrm{~min}-150 \mathrm{~min}$ by using a Durborid powder. The microstructure, phase constitution and oxidation behavior have been investigated. As result, $\mathrm{FeB}$ and $\mathrm{Fe}_{2} \mathrm{~B}$ phases were seen on the boride layer. $\mathrm{A}$ parabolic oxidation of the boride layer has been observed (Ptacinova et al., 2015).

In the literature, there are many surface treatment of boronizing studies on the effect of the process temperature and time on mechanical properties, chemical properties but no other studies have been found about composition of wt. \% Ekabor 2-pure iron. Because of this, we investigated pure iron, 5 wt. \% Ekabor 2, 10 wt. \% Ekabor 2 and 30 wt. \% Ekabor 2 powder mixtures. Sintered compacts were compared by their hardness of surface, density, wear abrasion and microstructure by each other. The primary goal of this study is to determine effect of composition quantity on the mechanical properties and wear abrasion.

\section{MATERIALS AND METHODS}

The samples were compacted by pure iron powders. The compositon of pure iron powders is $99 \mathrm{wt}$. \% pure iron $1 \mathrm{wt}$. \% kenalube lubricant as a binder. Iron powders mixed with different ratios of Ekabor 2 powders. The code of samples connected with chemical composition is shown as Table 1. Iron powders were generated by the Hougenes Co. and Ekabor 2 powders were generated by the BorTec too. The particle size of iron powder were 45-106 $\mu \mathrm{m}$ and size of Ekabor 2 powder were $<850 \mu \mathrm{m}$. Ekabor 2 powders have approximate chemical composition of $90 \% \mathrm{SiC}, 5 \% \mathrm{~B} 4 \mathrm{C}$ and $5 \% \mathrm{KBF} 4$. (Çalik, 2013). This chemical composition was used for calculating the theoretical density of pure iron powders.

All powder compositions which are given in Table 1 were mixed in a V-type mixer for $25 \mathrm{~min}$. with $25 \mathrm{cycle} / \mathrm{min}$ to obtain homogeneous mixture. After mixing process, the powders of Ekabor 2 and iron were placed in a steel die (outside diameter, $30 \mathrm{~mm}$; height, $80 \mathrm{~mm}$ ). A uniaxial pressure of 100 bar was applied to mixtures. The size of the obtained cylindrical compact was $\varnothing 30 \mathrm{~mm}$ in diameter, and it approximately weighted $20 \mathrm{~g}$. Height was different in each specimen depending on the intensity difference between Ekabor 2 and iron.

TABLE 1. The given codes, sintering temperatures and chemical compositions of composites of products

\begin{tabular}{|c|c|c|}
\hline Code & Chemical compositions of samples (wt. \%) & Sintering temperature $\left({ }^{\circ} \mathrm{C}\right)$ \\
\hline $\mathrm{C0}-01$ & 0 wt. \% Ekabor $2+100$ wt. \% Pure Iron & 900 \\
\hline $\mathrm{CO}-02$ & 0 wt. $\%$ Ekabor $2+100$ wt. \% Pure Iron & 950 \\
\hline C1-01 & 1 wt. $\%$ Ekabor $2+99$ wt. $\%$ Pure Iron & 900 \\
\hline C1-02 & 1 wt. $\%$ Ekabor $2+99$ wt. \% Pure Iron & 950 \\
\hline C3-01 & 3 wt. $\%$ Ekabor $2+97$ wt. \% Pure Iron & 900 \\
\hline C3-02 & 3 wt. \% Ekabor $2+97$ wt. \% Pure Iron & 950 \\
\hline C5-01 & 5 wt. $\%$ Ekabor $2+95$ wt. \% Pure Iron & 900 \\
\hline C5-02 & 5 wt. $\%$ Ekabor $2+95$ wt. \% Pure Iron & 950 \\
\hline C7-01 & 7 wt. \% Ekabor $2+93$ wt. \% Pure Iron & 900 \\
\hline C7-02 & 7 wt. $\%$ Ekabor $2+93$ wt. \% Pure Iron & 950 \\
\hline C9-01 & 9 wt. \% Ekabor $2+91$ wt. \% Pure Iron & 900 \\
\hline C9-02 & 9 wt. $\%$ Ekabor $2+91$ wt. \% Pure Iron & 950 \\
\hline C10-01 & 10 wt. \% Ekabor $2+90$ wt. \% Pure Iron & 900 \\
\hline C10-02 & 10 wt. \% Ekabor $2+90$ wt. \% Pure Iron & 950 \\
\hline C20-01 & 20 wt. \% Ekabor $2+80$ wt. \% Pure Iron & 900 \\
\hline C20-02 & 20 wt. \% Ekabor $2+80$ wt. \% Pure Iron & 950 \\
\hline C30-01 & 30 wt. \% Ekabor $2+70$ wt. \% Pure Iron & 900 \\
\hline C30-02 & 30 wt. \% Ekabor $2+70$ wt. \% Pure Iron & 950 \\
\hline C40-01 & 40 wt. $\%$ Ekabor $2+60$ wt. \% Pure Iron & 900 \\
\hline C40-02 & 40 wt. $\%$ Ekabor $2+60$ wt. \% Pure Iron & 950 \\
\hline C50-01 & 50 wt. $\%$ Ekabor $2+50$ wt. \% Pure Iron & 900 \\
\hline C50-02 & 50 wt. \% Ekabor $2+50$ wt. \% Pure Iron & 950 \\
\hline
\end{tabular}


All compacts were sintered by conventional furnace. Heating for sintering were used a PROTERM PAF $120 / 7$ furnace. In this sintering process compacts were sintered respectively at $900^{\circ} \mathrm{C}, 950^{\circ} \mathrm{C}$ for each composition of ratios in $4 \mathrm{~h}$. Each compacts were cooled naturally. The image of the produced samples are shown as Fig. 1 after successful sintering process. Iron based PM samples for sintering is approximately between $1100{ }^{\circ} \mathrm{C}$ and $1200^{\circ} \mathrm{C}$ under normal conditions, but we used $900{ }^{\circ} \mathrm{C}$ and $950{ }^{\circ} \mathrm{C}$ because of nearly $1149{ }^{\circ} \mathrm{C}$ is the melting temperature of the boron (Fichtl, 1981).

The relative densities of samples were measured by the Archimedes Method. The surface roughness was measured with Mitutoyo (2009) surface test device.

Ball on disc testing was used to evaluate the materials in a well-controlled multiple passage sliding contact. In this test $\mathrm{Al}_{2} \mathrm{O}_{3}$ ball was used and drown over surface several revolutions in the same circular track at a normal load of $10 \mathrm{~N}$ and a sliding speed of $25 \mathrm{~cm} \cdot \mathrm{s}^{-1}$, tangential (friction) and normal forces were continuously measured with strain gauges, recorded by computer. The width of abrasion surfaces was evaluated with optic microscopy images. Nikon Eclipse LV150N optic microscopy was used for microstructure images.

The surface hardness was evaluated before taking cross-section for comparing with internal hardness values. BMS-201-R Analog Rockwell Hardness Tester at automatic load of $150 \mathrm{~N}$ and a dwell time of $15 \mathrm{~s}$ was used for equipment. The values found are given at Table 5 .

The samples were then sectioned from bisect prepared metallographically up to 1200 grid emery paper and then polished using $1 \mu \mathrm{m}$ alumina paste. The Metkon Forcipol IV was used for etching and polishing. Microstructural characterization was made on product was made on product samples which had been polished and etched using a solution of $\mathrm{C}_{2} \mathrm{H}_{6} \mathrm{O}$ (97 vol. \%), $\mathrm{HNO}_{3}$ (3 vol. \%). Microstructures were observed with Nikon Eclipse LV150N optical microscope and obtained image is shown at Fig. 2.

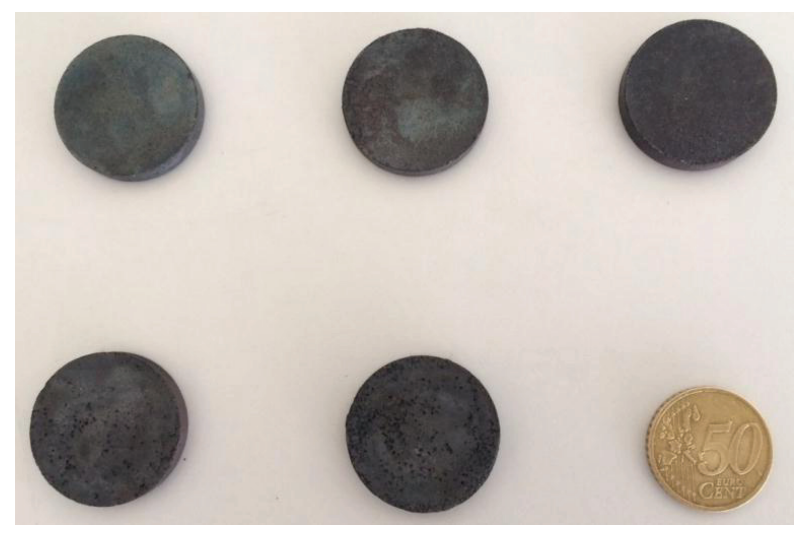

FIGURE 1. The image of the produced boron-iron samples and 50 cent coin.
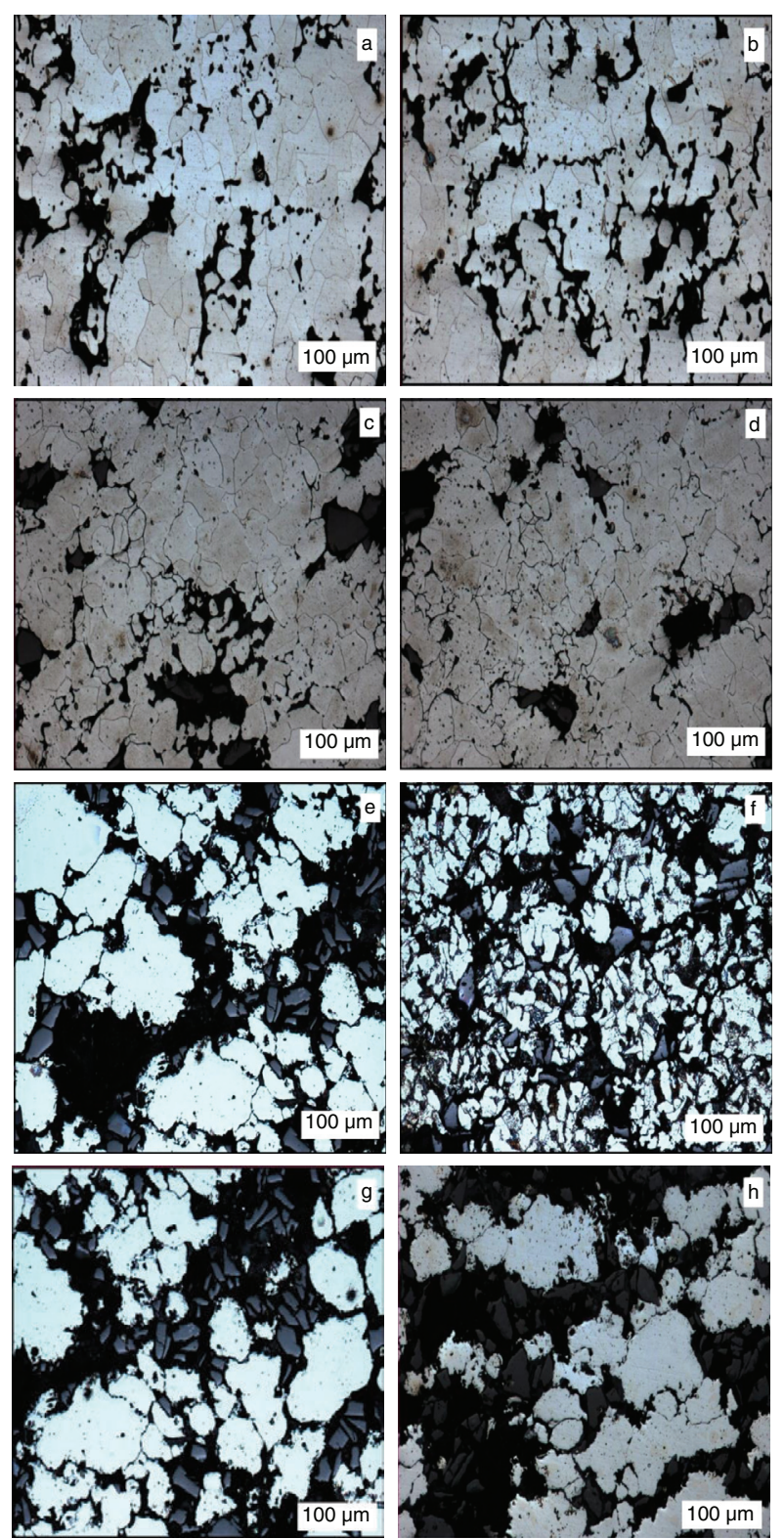

FIgURE 2. a) Pure iron PM samples was taken from the center of the surface of the microstructure image (x200) at $900{ }^{\circ} \mathrm{C}$; b) Pure iron PM samples was taken from the center of the surface of the microstructure image $(\mathrm{x} 200)$ at $950^{\circ} \mathrm{C}$; c) $5 \%$ by weight Ekabor 2 containing iron based powder metal (PM) samples was taken from near to corner surface of the microstructure image (x200) at $900{ }^{\circ} \mathrm{C}$; d) $5 \%$ by weight Ekabor 2 containing iron based powder metal (PM) samples was taken from near to corner surface of the microstructure image (x200) at $950^{\circ} \mathrm{C}$; e) $10 \%$ by weight Ekabor 2 containg iron based PM samples was taken from the center of the surface of the Microstructure image $(\mathrm{x} 200)$ at $900{ }^{\circ} \mathrm{C}$; f) 10

$\%$ by weight Ekabor 2 containg iron based PM samples was taken from the center of the surface of the microstructure image (x200) at $950{ }^{\circ} \mathrm{C}$; g) $30 \%$ by weight Ekabor 2

containing iron based PM samples was taken from near to the broken surface of the microstructure image (x200) at 900 ${ }^{\circ} \mathrm{C}$ and h) $30 \%$ by weight Ekabor 2 containing iron based

PM samples was taken from near to the broken surface of the microstructure image $(\mathrm{x} 200)$ at $950^{\circ} \mathrm{C}$. 


\section{RESULTS AND DISCUSSIONS}

The samples of weight and extension measurements were evaluated before sintering process and rate of change after process was shown at Table 2. Volume is maintained during sintering process. Therefore, while diameters of specimens were increasing, height of specimens decreased. Change in height and in diameter is due to gravity. Binder moved away during sintering process thus, weight decreased.

In a study of Çalik (2013), it was explained that composition of Ekabor 2 has obtained 90 wt. \% SiC; 5 wt. $\% \mathrm{~B}_{4} \mathrm{C} ; 5$ wt. $\% \mathrm{KBF}_{4}$ (Çalik, 2013). Densities of Ekabor 2 and pure iron were measured and percentage of density values were estimated. Results of experiment, it was found that density values changed between $6.7331 \mathrm{~g} . \mathrm{cm}^{-3}$ and $3.9647 \mathrm{~g} . \mathrm{cm}^{-3}$, percentage of density values changed from $86 \%$ to $72 \%$ (*Error range is $\pm 4 \%$ ). It's indicated that densities samples were decreased gradually from pure iron sample to pure iron-50 wt. \% Ekabor 2 samples. After Archimedes experiment, surface roughness test was applied to specimen and results are shown in the Table 3.
Three different values were taken from samples and the average of results were received. The table below, $R_{a}$ means arithmetic average of absolute values, $R_{y}$ is the maximum peak to lowest valley vertical distance within a single sample length and $\mathrm{R}_{\mathrm{z}}$ is a parameter that averages the height of the five highest peaks plus the depth of the five deepest valleys over the evaluation length (Mitutoyo, 2009). As shown below, when the amount of Ekabor 2 powder were increased, values of surface roughness were increased. Due to increase in temperature, surface roughness decreased and surface roughness occurred due to a portion of boron layer diffuse into the iron.

The abrasion test was applied to specimens. At the beginning and at the end of test their weights were measured. Then samples weight loss were calculated and it was given at Table 4. As expected, rate of Ekabor 2 increased by temperature and percent weight loss decreased. Because when rate of Ekabor 2 and temperature increased, wear resistance increased too. Also, after abrasion testing, the width of average abrasion surface was found between $1327 \mu \mathrm{m}$ and $904 \mu \mathrm{m}$ for $900{ }^{\circ} \mathrm{C}, 1616 \mu \mathrm{m}$ and $822 \mu \mathrm{m}$ for $950{ }^{\circ} \mathrm{C}(*$ Error range is $\pm 2 \%)$

TABLE 2. Percentage change of pellets height, pellets diameter and pellets weight (*Error range is $\pm 2 \%$ )

\begin{tabular}{lccc}
\hline Code & $\begin{array}{c}\text { Percentage height changes of sintered } \\
\text { compacts (\%) }\end{array}$ & $\begin{array}{c}\text { Percentage diameter changes of the } \\
\text { sintered compacts (\%) }\end{array}$ & $\begin{array}{c}\text { Percentage weight changes of the } \\
\text { sintered compacts (\%) }\end{array}$ \\
\hline C0-01 & $-3,22$ & 0,16 & $-0,36$ \\
C0-02 & $-3,19$ & 0,16 & $-0,14$ \\
C1-01 & $-3,68$ & 0,50 & $-0,28$ \\
C1-02 & $-3,26$ & 0,50 & $-0,37$ \\
C3-01 & $-3,06$ & 0,33 & $-0,21$ \\
C3-02 & $-2,45$ & 0,83 & $-0,10$ \\
C5-01 & $-3,92$ & 0,33 & $-0,19$ \\
C5-02 & $-2,00$ & 0,16 & $-0,16$ \\
C7-01 & $-0,99$ & 1,00 & $-0,19$ \\
C7-02 & $-1,94$ & 1,00 & $-0,15$ \\
C9-01 & $-1,92$ & 1,33 & $-0,26$ \\
C9-02 & $-1,86$ & 1,33 & $-0,13$ \\
C10-01 & $-1,85$ & 0,33 & $-0,65$ \\
C10-02 & $-1,78$ & 0,66 & $-0,16$ \\
C20-01 & $-2,41$ & 2,00 & $-0,11$ \\
C20-02 & $-0,80$ & 0,66 & $-1,42$ \\
C30-01 & $-2,85$ & 2,16 & $-0,51$ \\
C30-02 & $-0,56$ & 1,00 & $-1,58$ \\
C40-01 & $-1,25$ & 1,66 & $-1,77$ \\
C40-02 & $-1,22$ & 1,33 & $-1,88$ \\
C50-01 & $-0,33$ & 1,66 & $-1,02$ \\
C50-02 & $-1,66$ & 1,83 & $-2,01$ \\
\hline
\end{tabular}


TABLE 3. Average surface roughness values of samples (*Error range is between $\pm 1 \mu \mathrm{m}$ )

\begin{tabular}{lccc}
\hline Code & $\mathbf{R}_{\mathbf{a}}(\boldsymbol{\mu m})$ & $\mathbf{R}_{\mathbf{y}}(\boldsymbol{\mu m})$ & $\mathbf{R}_{\boldsymbol{z}}(\boldsymbol{\mu m})$ \\
\hline C0-01 & 2,98 & 21,73 & 14,15 \\
C0-02 & 2,77 & 21,23 & 13,59 \\
C1-01 & 3,04 & 24,84 & 14,84 \\
C1-02 & 2,97 & 21,25 & 14,04 \\
C3-01 & 3,77 & 24,96 & 15,00 \\
C3-02 & 2,99 & 21,30 & 14,25 \\
C5-01 & 3,93 & 25,34 & 16,90 \\
C5-02 & 4,11 & 21,57 & 18,02 \\
C7-01 & 4,20 & 25,55 & 17,71 \\
C7-02 & 4,31 & 22,27 & 19,15 \\
C9-01 & 4,98 & 25,85 & 20,62 \\
C9-02 & 4,39 & 23,40 & 20,11 \\
C10-01 & 4,72 & 30,00 & 21,61 \\
C10-02 & 4,50 & 25,89 & 21,81 \\
C20-01 & 4,82 & 32,79 & 22,65 \\
C20-02 & 4,75 & 30,49 & 22,86 \\
C30-01 & 5,50 & 33,62 & 23,29 \\
C30-02 & 6,43 & 37,77 & 24,19 \\
C40-01 & 6,37 & 35,34 & 23,58 \\
C40-02 & 6,60 & 38,50 & 24,77 \\
C50-01 & 6,63 & 40,98 & 23,85 \\
C50-02 & 7,10 & 41,58 & 24,96 \\
\hline & & &
\end{tabular}

Average values of internal and surface hardness were taken from three different spots evacuated. It is shown that at Table 5. Sintering results of materials without boron, the average surface and internal hardness were obtained approximately 28 and $32 \mathrm{HRC}$ or $286 \mathrm{HV}$ and $323 \mathrm{HV}$. When amount of boron increased, values of hardness increased and the average surface and internal hardness were obtained $73 \mathrm{HRC}$ and $66 \mathrm{HRC}$ or $1000 \mathrm{HV}$ and $866 \mathrm{HV}$ in the mixture containing $10 \mathrm{wt}$ \% Ekabor 2. The hardness of other samples couldn't be measured. Because during preliminary load of measurement the crack was occurred in specimens and values of hardness weren't shown at the Table 5. The study results were compared with Çavdar and Atik (2014b) and Cavdar et al. (2015). The boronizing process was applied to iron based powders, iron powder, $0-1$ wt. \% Al, 2-3 wt. \% and 0,2-0,8 wt. \% graphite (Çavdar et al., 2015), 1-6 wt. \% Cu; 0,2-0,8 wt. \% (Çavdar and Atik, 2014b) at $950{ }^{\circ} \mathrm{C}$. The average of hardness was found approximately $1000 \mathrm{HV}$ and in our study, the average of hardness was found $48 \mathrm{HRC}, 480 \mathrm{HV}$, at same temperature.

Morphology and microstructure of grain boundaries of PM compacts observed by optic microscopy are given in Fig. 2. Microscopy images showed that Ekabor 2 with gap was present in the iron layer in the
TABLE 4. Percent of weight loss of samples after abrasion testing process (*Error range is $\pm 1 \%$ )

\begin{tabular}{lc}
\hline Code & Percent weight loss (\%) \\
\hline C0-01 & 2,86 \\
C0-02 & 2,35 \\
C1-01 & 2,61 \\
C1-02 & 2,18 \\
C3-01 & 2,22 \\
C3-02 & 2,12 \\
C5-01 & 2,71 \\
C5-02 & 2,05 \\
C7-01 & 2,09 \\
C7-02 & 1,99 \\
C9-01 & 1,95 \\
C9-02 & 1,94 \\
C10-01 & 1,84 \\
C10-02 & 1,75 \\
C20-01 & 1,78 \\
C20-02 & 1,62 \\
C30-01 & 1,45 \\
C30-02 & 1,37 \\
C40-01 & 1,19 \\
C40-02 & 1,12 \\
C50-01 & 1,08 \\
C50-02 & 0,93 \\
\hline
\end{tabular}

form of fragments. Different phases are observed in images Fig $2 \mathrm{e}$ and Fig $2 \mathrm{f}$. It is estimated that $\mathrm{Fe}_{2} \mathrm{~B}$ and FeB phases occurred in 10 wt.\% Ekabor 2 and the best hardness values were taken from these specimens.

30 wt. \% by weight Ekabor 2 containing iron PM samples were taken from near to broken surface of the microscopy image (Fig. $2 \mathrm{~g}$, h). It is shown that rise of Ekabor 2 densities are obtained porosity which increase possibility of cracking. Phases of $\mathrm{Fe}_{2} \mathrm{~B}$ and $\mathrm{FeB}$ are shown at Fig. 2g. It is supposed that these phases make more brittle for the specimen. Ekabor 2 was seen as gray in the microstructure. Gray layer couldn't be obtained in the microstructure without Ekabor 2.

\section{CONCLUSIONS}

In this work, Ekabor 2 powder of different weights was mixed with pure iron powder specimens sintered at $900{ }^{\circ} \mathrm{C}$ and $950{ }^{\circ} \mathrm{C}$ for $4 \mathrm{~h}$ and the mechanical properties were investigated. These conclusions were reached:

- Densities of the samples were decreased due to increase values of Ekabor 2 powder.

- The surface roughness was increased due to increase value of Ekabor 2 powder. 
TABLE 5. Hardness values of samples (*Error range is between $\pm 3 \%$ )

\begin{tabular}{lcc}
\hline Code & $\begin{array}{c}\text { Surface hardness } \\
\text { (HRC) }\end{array}$ & $\begin{array}{c}\text { Internal hardness } \\
\text { (HRC) }\end{array}$ \\
\hline C0-01 & 25 & 31 \\
C0-02 & 32 & 33 \\
C1-01 & 35 & 38 \\
C1-02 & 40 & 41 \\
C3-01 & 37 & 39 \\
C3-02 & 43 & 41 \\
C5-01 & 40 & 42 \\
C5-02 & 45 & 45 \\
C7-01 & 42 & 44 \\
C7-02 & 47 & 45 \\
C9-01 & 53 & 55 \\
C9-02 & 54 & 59 \\
C10-01 & 69 & 64 \\
C10-02 & 75 & 68 \\
C20-01 & 25 & 31 \\
C20-02 & 32 & 33 \\
C30-01 & 35 & 38 \\
C30-02 & 40 & 41 \\
C40-01 & 37 & 39 \\
C40-02 & 43 & 41 \\
C50-01 & 40 & 42 \\
C50-02 & 45 & 45 \\
\hline
\end{tabular}

- The weight loss during wear abrasion was decreased due to increase values of Ekabor 2 powder till $10 \mathrm{wt}$. $\%$.

- The hardness increased due to increase ratio of Ekabor 2 powder and sintering temperature.

- Ekabor 2 PM made the material more brittle after percent of $10 \mathrm{wt}$ \% Ekabor 2.

- The optimum result in experiment was taken at 10 wt. \% Ekabor 2.

\section{ACKNOWLEDGMENTS}

The authors would like to acknowledge responsible for laboratory Mr. Gökhan Eyici for his assistance with optic microscopy images.

\section{REFERENCES}

Barut, N., Yavuz, D., Kayali, Y. (2014). Investigation of the kinetics of borided AISI 420 and AISI 5140 steels. $A K U J$. Sci. Eng. 14 (1), 1-8.

Çalik, A. (2013). Effect of powder particle size on the mechanical properties of boronized EN H320 LA steel sheets.
ISIJ International 53 (1), 160-164. http://doi.org/10.2355/ isijinternational.53.160.

Çalik, A. Karakaş, M.S., Uçar, N., Ünüvar, F. (2014). Boriding kinetics of pure cobalt. Kovove Mater. 52 (2), 107-112. http://doi.org/10.4149/km_2014_2_107.

Cavdar, U., Atik, E. (2011). Conventional and Rapid Sintering Techniques. CBU Soma Vocational School Technical Sciences Journal 1, 2-6.

Cavdar, U., Atik, E. (2014a). Investigation of conventional and induction sintered iron and iron based powder metal compacts. JOM 66 (6), 1027-1034. http://dx.doi.org/10.1007/ s11837-014-0977-0.

Cavdar, U., Atik, E. (2014b). Properties of Boronized, Carbonitrided and Steamed Iron-Based Compacts. Mater Test. 56 (2), 126-130. http://dx.doi.org/10.3139/120.110533.

Cavdar, U., Ünlü, B.S., Pinar, A.M., Atik, E. (2015). Mechanical properties of heat treated iron based compacts. Mater. Design 65, 312-317. http://dx.doi.org/10.1016/j.matdes.2014.09.015.

Celik, O.N., Akbayir, O., Gasan, H., Er, U., Aydınbeyli, N. (2008) Abrasive wear properties of borided AISI 1030 steel. Eng \& Arc. Fac. Eskisehir Osmangazi University 21 (1), 71-85.

Clark, D.E., Folz, D.C., Schulz, R.L., Fathi, Z., Cozzi, A.D. (1993). Recent Developments in the Microwave Processing of Ceramics. MRS Bulletin 18, 41-46.

Fichtl, W. (1981). Boronizing and its practical applications. Mater. Design 2 (6), 276-286. http://dx.doi. org/10.1016/0261-3069(81)90034-0.

German, R.M. (1996). Sintering Theory and Practice, Ed. John Wiley \& Sons, USA, pp. 313-362.

German, R.M. (2005). Powder Metallurgy \& Particulate Materials Processing, Ed. Metal Powder Industry, New Jersey, USA.

Günen, A., Carboğa, C., Kurt, B., Orhan, N. (2013). The Effect of Boron Powder Particle Size Used in Boriding Process on the Coating Layer. Nevsehir University Journal of Science $2(1), 12-19$.

Juijerm, P. (2014). Diffusion Kinetics of Different Boronizing Processes on Martensitic Stainless Steel AISI 420. Kovove Mater. 52 (4), 231-236. http://dx.doi.org/10.4149/ $\mathrm{km} 20144231$.

Jurci, P., Hudakova, M., Kusy, M. (2012). Nature of Phases in Boronized H11 Hot Work Tool Steel. Kovave Mater. 50 (3), 177-184. http://dx.doi.org/10.4149/km_2012 3 177.

Kasai, T., Ozaki, Y., Noda, H., Kawasaki, K., Tenamoto, K.(1989). Laser Sintered Barium Titanate. J. Am. Ceram. Soc. 72 (9), 1716-1718. http://dx.doi.org/10.1111/j.1151-2916.1989. tb06309.x.

Mitutoyo (2009). Surface Roughness Measurement, Bulletin 1984, Mitutoyo America Corporation, http://www.mitutoyo.com/ wpcontent/uploads/2012/11/1984_Surf_Roughness_PG.pdf

Ptacinova, J., Drienovsky, M., Palcut, M., Cicka, R., Kusy, M., Hudakova, M. (2015). Oxidation stability of boride coatings. Kovove Mater. 53 (3), 175-186. http://dx.doi. org $/ 10.4149 / \mathrm{km} 2015 \quad 3 \quad 175$.

Schatt, W., Wieters, K.P. (1997). Powder Metallurgy: Processing and Materials, European Powder Metallurgy Association (EPEMA), England.

Taştan, F., Akgün, S., Şahin, S. (2009). Analysis of effect of material composition to the properties of ferroboron layer in borozing. 5th International Advanced Technologies Symposium (IATS'09), Karabuk, Turkey.

Turku, N., Doğan, S., Uçar, N., Calik, A. (2014). The effect of boriding time on hardness values of low carbon micro alloyed steels. SDU Journal of Science 9 (2), 147-151.

Upadhya, K. (1987). Sintering Kinetics of ceramics and Composites in the plasma environment. JOM 39 (12), 11-13. http://dx.doi.org/10.1007/BF03257562.

Usta, M., Ekmekçiler, E. (2010). The Kinetics and Mechanical Study of borided iron aluminide ( $\mathrm{FeAl})$. Kovove Mater. 48 (4), 249-255. http://dx.doi.org/10.4149/km_2010_4_249. 